\title{
養殖アユにみられた抗酸菌性全身性多発性 肉芽腫形成について
}

和田新平*1・早川穣*1・ウィナイ ルバンヂョンディー*1 畑井喜司雄 ${ }^{* 1}$ ・篞 田三 朗 ${ }^{* 1}$ ・石井日出郎 ${ }^{* 2}$

(1991 年 3 月 5 日受付)

\section{Systemic, Multiple Granuloma Formation Caused by Acid-fast Bacteria in Cultured Ayu}

\author{
Shinpei Wada*1, Yutaka Hayakawa*1, Winai Rhoobunjongde*1, \\ Kishio Hatai ${ }^{* 1}$ Saburoh S. Kubota*1 and Hideo Ishii*2 \\ ${ }^{*}$ Division of Fish Diseases, Nippon Veterinary and Animal Science University, \\ Kyonan-cho 1-7-1, Musashino, Tokyo, Japan \\ *2 Tochigi Prefectural Fisheries Experiment Station,
}

(Received March 5, 1991)

\begin{abstract}
Histopathological studies were made on cultured ayu with systemic, multiple granuloma. Examined fish were collected from a farm in Tochigi Prefecture in 1989 and 1990. Macroscopically the disease was characterized by discoloration of the body, severely protruded eyes, and numerous small nodules on the surface of many organs as follows; liver, kidney, spleen, heart and intestine.

Histology showed that these nodules were granulomas composed of mononuclear cells and surrounded by the thin connective tissue. Granulomas were also found in gill filaments and trunk muscles. Gram-positive, selener, long rods were abundantly detected in the granulomas. Some of these long rods were also stained positively with Ziehl-Neelsen method for acid-fast bacteria and methenamine silver-nitrate stain (Grocott's variation).

From the results, the case of these fish was diagnosed as "systemic, multiple granuloma caused by acid-fast bacteria".
\end{abstract}

\section{緒言}

1989 年および 1990 年に, 栃木県下の A 養魚場で飼 育中のアユに，異常遊泳した後に整死する疾病が観察さ れた。病理組織学的に検討した結果, これらの罹病魚は 抗酸菌症であると判断されたので, その概要を報告す る。

\section{材料および方法}

今回検査した病魚は, 栃木県下の A 養魚場で 1989 年 5 月に採取したもの 4 尾（以下症例 1 と呼称する）拉よ び 1990 年 4 月に採取したもの 3 尾（以下症例 2 と呼

*1 日本獣医畜産大学

*2 杤木県水産試験場
称する）である。両症例とも栃木県漁協で生産した種苗 （湖産ではない）を育成したものである。症例 1 の病魚 (平均体重約 $30 \mathrm{~g}$ ) は旋回遊泳し, 時に池底に横臥する が刺激を加えると泳ぎだすといら異常行動を示した。こ れに対して症例 2 の病魚 (平均体重約 $20 \mathrm{~g}$ ) は旋回遊泳 を示さずに急死するというものであった。なお, 症例 2 の病魚の腎臓よりブレインハートインヒュジョン寒天培 地を用いて細菌分離を試みたが陰性であった。

これらの病魚は $10 \%$ リン酸緩衝ホルマリンで固定し, 常法に従って 4 5 $\mu \mathrm{m}$ のパラフィン切片とし, HE 染 色, PAS 反応, ギムザ染色, グラム染色 (Hucker-Conn 変法), グロコット染色, チール・ネルゼン染色, アザ ン・マロリー染色执よびアルデヒドフクシン染色を施し て光顕観察に供した。また, ホルマリン固定標本より戻 
し電顕の手法によって腎蔵の電顕標本を作製し, 観察に 供した。

\section{結果}

剖検の結果, 症例 1 のアユは肝臓表面に直径 $2 \sim 3$ $\mathrm{mm}$ 大の白色結節が散在しており, 腎臓の腫大も観察さ れた。症例 2 のユは同様の白色結節が肝臓, 腎臓, 脾 蔵, 消化管拈よび心蔵の各臓器の表面に密発しており (Fig. 1)，より重篤な症状を呈していた。

組織学的観察の結果得られた所見は両症例ともに共通 であったので, 以下に一括して述べる。肉眼的に認めら れた白色結節は組織内に形成された大小様々な肉芽腫で あることが確認された。これらの肉芽腫は腎蔵間質, 赤 脾髄内 (Fig. 2), 肝類洞内と実質細胞間 (Fig. 3), 鰓弁中 心静脈洞内と鰓薄板の間 (Fig. 4), 心室筋層内 (Fig. 5), 消化管の固有層から漿膜面までの部位, および軀幹筋線 維鞘間に形成されており, その形成頻度は両症例とも腎 臓および脾臓において高度であった。

両症例の諸臓器に形成されていた肉芽腫は未熟な類上 皮細胞と思われる細胞が不規則に配列しているのが特徵 的であり，成熟型の類上皮細胞肉芽腫のように細胞の同 心円状配列は認められず，多核巨細胞も認められなかっ た (Fig. 6)。また，肉芽腫周囲は踈な膠原線維によって 包囲され，形成初期段階と思われる肉芽腫周囲には 1 層 の線維細胞および線維芽細胞と疎な弾性線維が認められ た。

いっぽう,グラム陽性の長桿菌が未熟な類上皮細胞様 の細胞内拈よび細胞間に認められた (Fig. 7)。これらの 菌は分枝することはなく,さらにそれらの一部の菌はチ 一ル・ネルゼン染色 $(3 \%$ 塩酸アルコールを用いて脱色 した）およびグロコット染色に陽性を示し，殊にチー ル・ネルゼン染色では連珠状ないし虎の尾状に染色され た。電顕的にこれらの長桿菌の直径は約 $0.5 \mu \mathrm{m}$ であり, 単核性細胞の内部に取り込まれているものも散見された (Fig. 8)。

\section{考察}

イクチオホヌス症 (Miyazaki and Jo, 1985) 罹病アニ は類似の白色結節を腹腔内臟器に形成し, その内部に多 核球状体が認められることが特徵であるが，今回の症例 には多核球状体を見出すことはできなかった。これに対 して本症例の肉芽腫はその組織学的特徵から Adams (1983) の分類による成熟型肉芽腫ないしは未熟型類上皮 細胞肉芽腫に相当するものと判断された。舟橋ら (1973)
はウグイおよびカワムッにみられた本症と類似の全身性 多発性結節症を報告しているが，それらは比較的境界明 瞭な間葉系細胞の集簇であり, 肉芽腫周囲に結合組織が ほとんぞ認められず，さらに組織内に細菌が検出されな かった点で本症例とは異なる組織学的特徵を有してい る。

肉芽腫内部に認められたグラム陽性の長桿菌はその染 色性から抗酸菌であると考えられた。魚類の抗酸菌症は Bataillon et al. (1897) がュイについて報告して以来, 多 くの魚種で存在することが知られており (Frerich and Roberts, 1989), 病理組織学的に中心部の乾酪化を伴う 類上皮細胞肉芽腫を形成することが特徵であるとされて いる（森ら, 1986; Chinabut et al., 1990)。しかしなが ら, 本症例は成熟型肉芽腫ないし未熟型類上皮細胞肉芽 腫の全身性かつ多発性の形成が特徵的であり, 定形的な 魚類の抗酸菌性肉芽腫病変とは異なった病理組織学的特 徵を示した。本症例の病理組織学的特徵は宿主であるア ユ，または感染していた抗酸菌の種類に起因するものな のかは不明であった。しかしながら，今回養殖アユにも 抗酸菌症が存在することが示唆されたことから，今後は 本症をアユの疾病の類症鑑別項目に加える必要があると 考える。

以上の点より, 今回の 2 症例を病理組織学的に抗酸菌 性全身性多発性肉芽腫形成と診断した。

\section{要約}

1. 1989 年および 1990 年に栃木県下の一養魚場で飼 有中のアユに原因不明の整死がみられたので, 病理組織 学的に検查した。

2. 供試魚は肉眼的に大小様々な白色結節が肝臓, 腎 臓, 脾藏, 心臓, 鰓弁, 消化管および軀幹筋に多数形成 されており,これらは組織学的に成熟型肉芽腫ないしは 未熟型類上皮細胞性肉芽腫と判断された。

3. これらの肉芽腫内部には, グラム染色に陽性を示 す長桿菌が認められた。これら長桿菌の一部はチール・ ネルゼン染色およびグロコット染色にも陽性を示したこ とから, 抗酸菌であると考兄られた。電顕観察の結果, これら長桿菌の直径は約 $0.5 \mu \mathrm{m}$ であった。

4. 以上の所見から, 本症例を病理組織学的に抗酸菌 性全身性多発性肉芽腫形成と䛦断した。

\section{文献}

Adams, D. O. (1983): The biology of the granuloma. In "Pathology of granulomas" (ed. by 
H. L. Ioachim). Raven Press, New York, pp. 120.

Bataillon, E., L. Dubard and L. Terre (1897): Un nouveau type de tuberculose. C.r. Seanc. Soc. Biol., 49, 446-449.

Chinabut, S., C. Limsuwan and P. Chanratchakool (1990): Mycobacteriosis in the snakehead, Channa striatus (Fowler). J. Fish Dis., 13, 531535.

Frerichs, G. N. and R. J. Roberts (1989): The bacteriology of teleosts. In "Fish pathology, 2nd edition” (ed. by R. J. Roberts). Bailliere Tindall,
London, Philadelphia, Sydney, Tokyo, Toronto, pp. 315-317.

舟橋紀男 - 宮崎照雄 - 窪田三朗 - 富永正雄 - 塩瀬淳也 (1973)：ウグイおよびカワムッの稚魚に発生した全 身性多発性結節症. 魚病研究, 8, 55-63.

Miyazaki, T. and Y. Jo (1985): Studies on ichthyophonus disease of ayu. Fish Pathology, 20, 45-48.

森 利之・畑井喜司雄・崔田三朗 (1986) : 抗酸菌に感 染したフエヤッコダイの病理組織学的所見. 日本獣 医畜産大学研究報告, 35, 141-145. 


\section{Explanation of Figures}

Fig. 1. Macroscopical feature of a diseased fish (case 2), showing nodules (arrows) found on the surface of liver and intestine.

Fig. 2. Multiple granulomas (arrows) in the red pulp of spleen.

Aldehyde fucsin stain. Bar: $200 \mu \mathrm{m}$.

Fig. 3. A granuloma in liver parenchyma composed of mononuclear cells and surrounded by the thin connective tissue.

Azan-Mallory stain. Bar: $50 \mu \mathrm{m}$.

Fig. 4. Multiple granuloma formation in central venous sinuses (arrow head) and under secondary gill lamellae (arrow).

Aldehyde fucsin stain. Bar: $200 \mu \mathrm{m}$.

Fig. 5. A granuloma in cardiac muscles surrounded by the thin connective tissue.

Azan-Mallory stain. Bar: $100 \mu \mathrm{m}$.

Fig. 6. High magnification of the granuloma in liver parenchyma composed of mononuclear cells (arrow) similar to immature epithelioids in irregular arrangement.

HE stain. Bar: $20 \mu \mathrm{m}$.

Fig. 7. A colony of Gram-positive, slender, long rods (arrow) in the granuloma in the spleen. Gram stain (Hucker-Conn method). Bar: $10 \mu \mathrm{m}$.

Fig. 8. Long rods of about $0.5 \mu \mathrm{m}$ in diameter (arrows) phagocytized by mononuclear cell (arrow head) in the granuloma in the kidney.

Bar: $3 \mu \mathrm{m}$. 


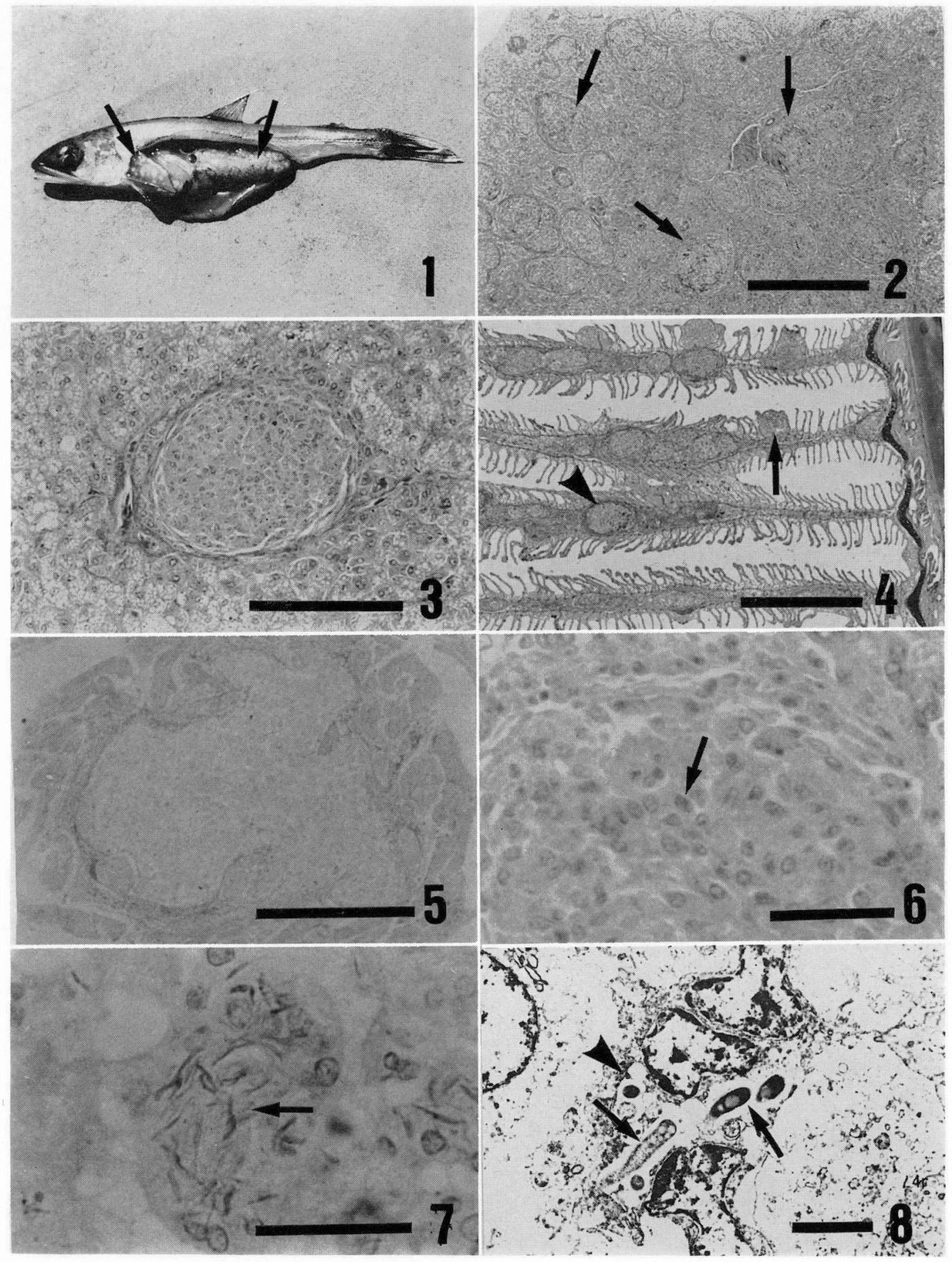

